\title{
Abdurrahman Abdî Paşa'nın Pendname Şerhi İle İsmail Hakkı Bursevi'nin Pendname Şerhi'nin Karşılaştırılmasıı ${ }^{1}$
}

\section{A Comparıson of Abdurrahman Abdî Paşa's Pendnames and İsmail Hakkı Bursevi's Pendname \\ Fatih YERDEMIR*}

\begin{abstract}
Öz
Türklerin kültür yaşamında ve tasavvufi irfanın gelişmesinde önemli bir yer sahibi olan Ferididdün Attar'ın Pendnâme adlı eseri, Türk edebiyatının yansıra Dünya edebiyatında da beğenilerek okunmuş ve Türkçe dâhil birçok dile tercümesi yapılmıştır. Günümüzde bu eser üzerine yapılan çalışmaların çokluğu ve bunun yanında Farsça aslından Türkçeye tercümelerinin hâlâ yapılmaya devam edilmesi; bu meşhur eserin içerisindeki bilgilerin, ahlak anlayışının günümüzde bile ölümsüz olduğunu ortaya koymaktadır. Bu eser o kadar çok sevilmiş ve benimsenmiştir ki edebiyatımızda bu eserin adıyla anılan edebi bir tür ortaya konulup ona öykünen eserler yazılmıştır. İnsanlara daha iyi bir insan olmayı ögütlemek için yazılan ve manzum bir eser olan Pendname, hem geniş halk kitlelerini ve hem de devleti yönetenleri ahlâki yönden olgunlaştırmayı, erdemli kılmayı amaçlamıştır. İrfan sahibi ediplerimiz tarafından asırlar boyunca pendname; tercüme edilmiş, kendilerinden birtakım öğütler katarak yani genişleterek telif-tercüme özelliği gösteren bir forma büründürülmüş ya da daha iyi anlaşılması için şerh edilmiştir. $\mathrm{Bu}$ eser, hem tercüme, hem telif-tercüme hem de şerh edebiyatımıza çok önemli eserler kazandırmıştır. Pendname'nin daha iyi anlaşılması için yazılan şerhlerde üdebanın kendi mizaçları, anlayışları, inançları ve hayata bakış açılarındaki farklılıklar eserlerine yansımıştır. Bu şerhler de kendi içinde zamanla asıl kitaptan bağımsız telif bir eser gibi anılmaya başlanmıştır. Bu çalışmada Abdurahman Abdî Paşa'nın pendname şerhi ile İsmail Hakkı Bursevî’nin pendname şerhi karşılaştırılaştırılmış. İki şerhin birbirine benzeyen yönleri ve farklılıklarını ortaya konmaya çalışılmıştır.
\end{abstract}

Anahtar Kelimeler: Şerh, Pendname, Karşılaştırma, Abdî Paşa, İsmail Hakkı Bursevî.

\begin{abstract}
The work of Ferididdün Attar, who has an important place in the cultural life of Turks and the development of mystical wisdom, has been read with appreciation in the world literature as well as in Turkish literature and has been translated into many languages including Turkish. Today, the abundance of studies on this work, as well as translations from Persian original to Turkish, are still being made; It reveals that the information and moral understanding in this famous work is immortal even today. We loved and adopted this work so much that we have created a literary genre named after this work in our literature and wrote works that emulate it. The Pendname, a verse work written to advise people to be a better person, aimed to make both the masses of the people and those who govern the state morally mature and virtuous. For centuries pendname by our wise men; It has been translated, by adding some advice from them, that is, by expanding it, it has been transformed into a form that shows copyright-translation feature or has been annotated for better understanding. This work has brought very important works to our translation, copyright-translation and commentary literature. In the commentaries written for a better understanding of the Pendname, the differences of the udeban's own temperaments, understandings, beliefs and point of view on life are reflected in his works. In time, these annotations started to be known as a copyrighted work independent from the original book. In this study, the pendname annotation of Abdurahman Abdî Pasha and İsmail Hakk1 Bursevî's pendname commentary will be compared. It will be tried to reveal the similar aspects and differences of the two commentaries.
\end{abstract}

Keywords: Commentary, Pendname, Comparison, Abdî Pasha, İsmail Hakkı Bursevî.

\section{Giriş}

Şerh, tercümeden farklı olarak eseri her yönü ile ele alıp açıklamalar yapmaktır. Tercümede birçok anlam tam olarak verilememektedir. Birçok yer de kavramların aktarılan dile

\footnotetext{
* Dr. Gazi Üniversitesi, TÖMER, fatihyerdemir@ hotmail.com

${ }^{1} \mathrm{Bu}$ makale, 24-25 Haziran 2020 tarihleri arasında Ankara'da çevrimiçi olarak düzenlenen Uluslararası Genç Bilim ve Sanat İnsanları Sempozyumu (GEBSiS)'na "İsmail Hakkı Bursevi'nin Pendname Şerhi İle Abdurrahmân Abdî Paşa'nın Pendname Şerhinin Karşılaş̧ırılması" bildirinin düzenlenmiş ve genişletilmiş halidir.
}

Yerdemir, F., (2021). Abdurrahman Abdî Paşa'nın Pendname Şerhi İle İsmail Hakkı Bursevi'nin Pendname Şerhi'nin Karşılaştırılması, Asia Minor Studies, Cilt 9 Sayı 1, 602-620, Gönderim tarihi: 06-11-2020, Kabul tarihi: 09-01-2021.

Araştırma Makalesi. 
tam anlamıyla çevirisi yapılamamakta; yazarın ne demek istediği ve kendi dilindeki ifade gücü ve özellikleri tercümede ortaya çıkamamaktadır.

Ecdadımız Farsça ve Türkçe bilgilerini ortaya koyarak eserleri şerh ederken karşılaştırmalı olarak iki dilde ortaya çıkan bütün anlam, ses ve gramer özeliklerini aktarma yoluna gitmişlerdir. Şerhler bu yönüyle sadece edebî eseri anlamak için yazılsa dahi onu okuyanlar için iki dilin zenginliklerini ortaya koyması bakımından da önemlidir.

Şerhi yazan kişinin meşrebi, dünyayı algılaması, eğitimi, yaşadığı çevre şerh ettiği metinde ortaya çıkar. Şarih, şerhini yazarken bu zamana kadar edindiği, gördüğü bütün bilgi birikimini yazdığı esere döker. Açıklamalarını yaparken yararlandığı kaynaklar varsa onlara göndermeler yapar. Bu tür eserlerde en çok yararlanılan kaynaklar sözlüklerdir. Şarih, elinin altında bulunan, herkes tarafından okunan ve bilinen sözlüklere atıf/gönderme yapabildiği gibi açıklamalarında kendine destek olması mahiyetinde tarihî, dinî eserlerden de yararlanabilir. Bazen bu eserler metnin anlaşılmasında yeterli olmazsa şerh edilen metne benzer metinlere -ki bunlar divan, mesnevi ve ahlak içerikli eserler olabilir- başvurur. Açıklanan ifadeler dini içerikli ise Kuran-1 Kerim'e ve Hadislere ve tasavvufi eserlere göndermeler yapılır, anlatım derinleştirilip yazarın/şairin ne demek istediği ortaya çıkarılmaya çalışılır.

Şarih, şerh ettiği metinde anlamı bulabilmek için bazen kaynak dilden gramer kurallarını, şerh ettiği dil ile karşılaştırma yoluna gider. Bir eş değerlilik yakalamaya çalışarak iki dil arasında hem kelime bazında hem de cümle bazında bir karşılaştırma yapar. Bu karşılaştırma da bazen bir kelimenin bazen de bir kalıp ifadenin iki dil arasındaki seyri de ortaya çıkar. Ortak kelimeler, deyimler, atasözleri ve kalıp ifadeler genelde şerh metinlerde çok sık ortaya çıkan malzeme türüdür. Bunların yanı sıra kavramda oluşan benzerliklerin iki dilin ses ve cümle dizgesinde aynı olmayıp farklı şekillerde yansıdığ 1 yerler de olabilir. Bu da şerhlerde, iki dilin birbirileriyle olan alışverişlerinin kelime ve cümle düzeyinde değil de anlayış ve idrak düzleminde de ortaya çıktığını şerhlerde gözlemleyebiliriz.

Şerhlerde takip edilen yöntemlerden biri de şerh edilen eserin tek nüshası yerine başka nüshalarının da görülüp varsa nüsha farklılıklarına yer verilip açıklama yapılmasıdır. Şarihler farklı nüshaları görüp kendilerince sahih nüsha/nüshalar olarak adlandırdıkları eserleri şerh ederken aynı eserin başka nüshalardaki farklılıklarına da dikkati çekerler. Diğer nüshalardaki farkl1, olan kelime, cümle ve ibareleri tespit ederek bir nevi edisyon kritik yaparlar. Bazen şarih, farklı nüshadaki bölümü kelime ve cümleyi de açıklayarak o nüshadaki anlamın da ortaya çıkmasını sağlayabilir.

Şerhlerde ortaya çıkan diğer bir durumda reddiyeledebi eleştiri yöntemidir. Şarih, aynı eseri şerh eden başka bir şarih varsa; onun şerhini anlam, okunuş, gramer ve kültürel olarak eleştirir. Diğer şarihin yaptığı açıklamayı beğenmez. Ona reddiye yazar. Bazen şarih, şerh ettiği edebî eseri de eleştirir yani esere dönük eleştiri yapar. Bu da şarihin bir eser nasıl olmalıdır? sorusunun cevabını aramasıdır.

Bu çalışmada Pendname’ye şerh yazan İsmail Hakkı Bursevi'nin şerhi ile Abdurrahmân Abdî paşanın şerhleri anlam ve yapı bakımından karşılaştırılacaktır.

İki şarihin de Pendname'yi şerh etme üsluplarının benzerlikleri yanında farklılıklarının olup olmadığı tespit edilecek. Şarihlerin kelimenin en küçük yapı taşı olan harfe kadar inip yanlış okuma ve bu yanlış okumadan kaynaklanan anlam yanlışlıklarının ortaya çıkmasını engellemek için harfin nasıl okunması gerektiğine kadar eseri inceleyip incelemedikleri üzerinde durulacaktır.

Yapı başlığı altında şarihlerin, Pendname'yi şerh ederken harf, hece, kelime ve cümle yapılanmalarını nasıl ele aldıkları üzerinde durulacaktır. Şarihlerin şerhlerinde yer verdikleri ve bir dilin sahip olduğu kültürel söz varlıkları da ortaya konacaktır. İki şarihin birbirlerinden 
farklı harf seslendirmesi, aynı kelimenin cümle içerisindeki iraplarının benzer ya da farklılıkları tespit edilecektir. Şarihlerin bazen iki dil üzerine yaptıkları gramer açıklamalarına bakılacaktır.

Anlam başlığı altında şarihlerin kelimeyi gerçek, terim, mecaz ve irfani olarak nasıl anlamlandırdıkları üzerinde durulacaktır.

İsmail Hakkı Bursevî Pendname’ye yazdığı şerhe özel bir ad vermemiştir, ama Abdurrahmân Abdî Paşa yazdığı şerhe Müfîd adını vermiştir. Bu eserlerden yapılan alıntılar için İsmail Hakkı Bursevî'nin şerhi Bursevî; Abdurrahmân Abdî Paşa'nın şerhi, Müfîd olarak aktarılacaktır.

\section{Abdurrahman Abdî Paşa'nın Şerhçiliği' ${ }^{2}$}

Abdurrahman Abdî Paşa, şerh ettiği Pendname’ye Müfîd adını vermiştir. O, Pendnameyi şerh etmesinin nedenini isteyenlere ve öğrencilere Farsça öğretmek için yazdığını, eserinde birkaç defa "ṭâlib-i taḥṣ̂ll-i Fârsî" ifadelerini zikretmesinden anlaşılmaktadır. O, Pendnameyi şerh etmeye, eserin metninden beyitlerin şerh edeceği yere aslını yazmakla başlamıştır. Sonra her harf ve kelimeyi tek tek okunuş, mana ve gramer özelliklerini incelemiş̧tir. Harf ve kelimelerin çekimleri ve türeyişleri üzerinde durmuş, onların söz öbekleri ve cümledeki yerleri ile ilgili bilgiler vermiştir. En sonunda mahṣ̂ul-i beyt bölümünde beytin manasını açıklayarak şerhini tamamlamıştır.

Abdî Paşa'nın, şerhinde hareke yoktur. O, ana metinde geçen kelimelerin ve harflerin tek tek okunuşunu vermiştir. Arapça ve Farsça da farklı seslendirilen harflerin özeliklerini dile getirmiş, kelimeyi bu dillerdeki şekliyle okunmasının gerektiğine dikkat çekmiştir. Kimi zaman bazı kelimelerin vezin gereği okunuşlarında farklılıklar olabileceğini söylemiştir.

Müfîd'de, kelimelerin gerçek anlamı için lugat; terim anlam için istılah; mecaz anlam için murâd kelimelerini kullanmıştır. Bazı durumlarda lâkin bunda ve bu mahalde ifadelerinden sonra açıklanan kelimenin cümlede ortaya çıkan manasını vermiştir. Anlamını önceden söylediği kelime bir daha geçtiğinde sabıkan beyân oldu ifadesini kullanmıştır. Bazen Arapça kelimeleri açıklarken onların hangi babdan geldiklerini söyledikten sonra anlamlarını vermiştir. Bazı kelime ve eklerin birden fazla anlamları olduğunu her birini mahallinde beyân olacağını ifade etmiştir. Bazı sözcüklerin kaç anlamı varsa onları teker teker dile getirmiştir.

Yeri geldiğinde kaynak dil ile ilgili bazı dilbilgisi kuralları açıkladığı yerler vardır. Çok nadiren de edat olarak kullanılan harflerin Arap gramerinde neye karşılık geldiğini söyleyip iki dili mukayese ettiği yerlerde bulunmaktadır.

Beytin anlamını verdiği maḥsûl-i beyt bölümünde derinlemesine bir açıklamalara girmez. Yaptığı açıklamaları daha çok tercüme şeklindedir.

\footnotetext{
${ }^{2}$ Asıl adı Abdurrahman olan Abdî Paşa, İstanbul'da Anadoluhisarı'nda doğmuş, Enderûn-1 Hümâyun'da eğitim görmüştür. Vekâyi ‘nâme'sinde 27 Ekim 1648'de Sarây-1 Hümâyun'da Büyük Oda'da görev aldığını, 1650'de Seferli Koğuşu'na geçtiğini, 1659'da da Has Oda'ya nakledildiğini, 1665'te kendisine “tuğra çekme” yetkisi verildiğini, 1668'de sır kâtibi olduğunu, 28 Temmuz 1669'da vezâret rütbesi ile nişancılık mansıbına tayin edilmek suretiyle saraydan çıktığını dile getirmiştir. Nişancılık mansıbında uzun süre hizmet veren Abdi Paşa, ordunun Çehrin Seferi’ne hareketinde (15 Mart 1678) İstanbul kaymakamlı̆̆ına getirilmiş. Bir yıl sonra da dördüncü vezirliğe terfi ettirilmiş. 1680 Ekiminde yeniden İstanbul kaymakamı olmuş, eylül 1682'de de ikinci vezir bulunduğu sırada Basra valiliğine tayin edilmiştir. On yıl kadar çeşitli eyaletlerde valilik yaptıktan sonra ikinci defa Basra valiliğine, 1690'da da Kandiye muhafızlığına nakledilmiştir. Buradan gönderildiği Sakız muhafızlı̆̆ı görevindeyken vefat etmiştir. "Abdî” mahlası ile yazdığı şiirlerini bir divanda toplayan Abdi Paşa'nın, ayrıca Attâr'ın Pendnâmesi ile Kâ‘b b. Züheyr'in Kasîde-i Lâmiyyesine (Kasîdetü'l-bürde) ve Dîvân1 'Urfî' deki bazı şiirlere şerhler de yazmıştır (Derin, 1988, s. 74-75).
} 


\section{İsmail Hakkı Bursevî’nin Şerhçiliği ${ }^{3}$}

Mesnevi nazım şeklinde kaleme alınan Pendname'yi İsmail Hakkı şerh etmeye başlamadan önce orijinal metinden beyit ya da mısraı şerh yapacağı yerin başına yazmıştır. $\mathrm{Bu}$ bölümde şerh edeceği boyuta göre kimi zaman beyti kimi zaman bir mısra1 ele almıştır. Şerhin ilk başında İsmail Hakkı, ek ve kelimelerin anlamlarını, diğer dillerde karşılıklarını (Arapça ve Farsça) ve o kelimenin Türkçedeki anlam ile kullanım yerlerini vermektedir. Sonra kelimelerin diğer kelimelerle kurduğu ilişkilerden ve cümledeki yerlerinden bahsetmiştir. Okunmasında hata olacak veya farklı okumalarla farklı anlamlara gelebilecek kelimelerin okunuşunu vermiştir. Kimi zaman harflerin Arapça ve Farsça da farklı okunabileceğine dikkat çekmiştir. En sonunda da ma 'nâ-yı beyt budur ki/ma 'nâ-yı mıșrâ' budur ki ifadeleri altında şerhini tamamlamıştır.

Bazı kelimelere yaptığı açıklamalarda hiçbir sözlüğe veya kitaba gönderme yapamamışsa buradaki tutumu kendince açıklamıştır. Bu açıklamaları yaptığı yerde bu fakir ifadesini kullanarak öznel bir yorum yaptığını dile getirmiştir. Anlamını önceden açıkladığı kelimelere tekrardan bir açıklama yapmamıştır. Bu durumda da tafșîli mürur itmiş gibi bir ifade kullanmıştır.

İsmail Hakkı'nın şerhinin en önemli yönü kelimelerdir. O, kelimeyi okunuşundan anlamına, oradan da cümledeki yerine kadar irdelemiştir.

Şerhin ilerleyen kısımlarında İsmail Hakkı, şerh yöntemini biraz değiştirmiş, mısra1/beyti nesre çevirmekle işe başlamıştır. Arkasından cümle tahliline girişmiş, sonra kelimelerin şekil (sarf) ve anlam (mana) boyutunu irdelemiştir. Beyti/mısraı nesre çevirmeyi bunuñ takdîri/bu mıșrâ 'ıñ takdîri/bu beytüñ takdîri ifadesi ile yapmaya başlamış ve dimekdür ifadesi ile bitirmiştir. Nesre çevirme işinden sonra bu beytüñ i 'râbı z̧âhirdür diyerek cümleyi tahlile girişmiştir. Bursevî, Arapçayı çok iyi bilen bir kişidir. Açıklamalarında kullandığı terimlerin büyük bir kısmı da Arapçadır. Bu yoğun Arapça anlatımında birkaç beyti nesre çevirirken Farsça yazması gerekirken Arapça yazmıştır.

Şerhindeki sonraki adım ele aldığı metinle diğer nüshalar arasında farklılık varsa eğer bu duruma dikkati çekmesidir. Bunu da ba 'żı nüsh̆ada ifadesini kullanarak yapmıştır. Dikkatini çektiği nüsha farklılığını şerh ettiği yerler de vardır. Bazen şerh etmeden sadece nüsha farklılığından bahsetmiştir.

Şerhindeki önemli bir özellikte yer yer Arapça, Farsça ve Türkçe dilbilgisi kuralları anlatmasıdır. Bunda bir düzen olmaksızın kendince uygun gördüğü yerlerle ilgili olarak bilgi vermesidir.

\footnotetext{
${ }^{3} 1653$ yılının ekim bugün Bulgaristan sınırları içinde bulunan Aydos’ta doğmuş. Uzun süre Bursa'da yaşadığ için Bursevî, bir süre Üsküdar'da ikamet ettiğinden Üsküdârî, Celvetiyye tarikatına mensup olduğu için Celvetî nisbelerini kullanmış, özellikle Bursevî nisbesiyle meşhur olmuştur. Tamâmü'l-feyż ve Silsilenâme-i Celvetî başta olmak üzere bazı eserlerinde hayatı hakkında bilgi veren İsmâil Hakkı'ya dair çalışmalar esas itibariyle bu bilgilere dayanmaktadır. Hareketli bir hayat geçirdiğinden bu çalışmalarda yer yer eksiklik ve yanlışlıklara rastlanmaktadır. 100'den fazla eser yazdığını belirten İsmâil Hakkı bunların bir kısmının adını da zikretmiştir. Bazı eserlerinin birden fazla ismi olması, mecmua ve vâridât türü kitaplarının birbirine karıştırılması gibi sebeplerle eserlerinin sayısı çok farklı gösterilmiştir. Çok yönlü olan edibimiz, şair ve şarih kimliğinin yanı sıra müfessir kimliğiyle de öne çıkmıştır (Namlı , 2001, s. 102-106).
} 


\section{Karşılaştırma}

\section{Kelimelerin Okunuşu}

\section{Bursevit}

Bursevî'nin Pendnâme șerhinin metni harekelidir. Kendince bazı durumlarda anlam karışıklılığının önüne geçmek için kelimelerin okunuşu hakkında bilgi vermiştir. Bunu da iki şekilde yapmıştır. Birincisi harfin fetha, damme, kesre ve sükun mu okunacağını dile getirmesi; ikinci olarak kelimenin Arapça bir kural olarak hangi vezinde olduğunu, herkesin bildiğini düşündüğü örnek kelime ile birlikte vermesidir. Bazı kelimelerin kesre ya da fethalı okunması anlam değişikliğine yol açtığına dikkati çekmiştir. Bazı kelimelerin ikili şekilde okunabileceğini dile getirmiştir. Bu durum metindeki bütün kelimeler için geçerli değildir. Bursevî, şerh metni harekeli olmasına karşın okuyucunun dikkatini çekmek için yapmış olmalıdır. $4 b)$.

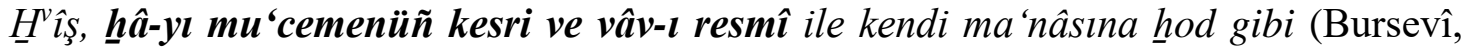

Șabr bânuñ sükûnıla nefsi kerâhet itdügi nesne üzerine habs itmege dirler (Bursevî 9a).

Mâlik serrî veyâ hibe veyâ irs ile bir nesneye mutașarrif olana dirler bu ș̂uretde milkden olur kesrile ve mâlik kavî şedîd ma 'nâsına dahı gelür bu șûretde melkden olur feth-i mîm ve sükûn-ı lâm ile ki ḳuvvet ü şiddet dimekdür (Bursevî, 30a-30b).

Hâtem tânuñ feth ve kesriyle parmag்a takdıklarl zînetdür ki anuñla nesne mühürlenür. (Bursevî, 8b).

Bazı kelimelerin vezin gereği tahfif okunabileceğini dile getirmiştir:

Ferr teşdîd ile bu dahı Fârsî̀ür burada tahfîf olundig̀ı vezn içündür ma 'nâsı kuvvet ü revnak ve terâvet ü fürûg dimekdür. (Bursevî, 30b).

Bazen harflerin Arap ve Fars dillerindeki farklı olarak seslendirildiğini ifade etmiştir:

kücâ kâf-ı 'Arabînüñ dammıyla ḳande dimekdür (Bursevî, 80b).

Bazı kelimelerin harflerinin okunuşunu vermez ama Arap gramerinde ve sözlükçülüğünde geçerli bir kaideyi kullanır. O kelimenin Arap gramer kurallarına göre veznini ve örnek kelimeyi verir: $30 b)$.

Zufer șured vezni üzerine esed $\ddot{u}$ şücâ' ve baḥr ma'nâlarına gelür (Bursevî,

Evliyâ velînüñ cem 'idür nebî vezni üzerine (Bursevî, 22a).

Bursevî, Arapça okunuşu kolay olsun diye verilen vezin örneklerine Türkçe bir kelimenin okunuşu için de vermiştir:

Küngerân çavdar ki buġdaydan döner vezni üzredür (Bursevî, 68a).

Bazı kelimelerin halk ağzında farklı söylendiğini ifade etmiştir:

Haşm hâa-yı mu'cemenün fethiyle egerçi lisân-ı nâsde kesrile mütedâvil ü meşhûrdur șavab ma 'nâsınadur ki Türk kakımak dir. (Bursevî, 139b)

\footnotetext{
${ }^{4}$ Metin incelenmesinde kullanılan yazma nüsha: Şerh-i pend-name-i Attar [mikroform]/ Şarih: İsma'il Hakk1 Bursavi; müstensih: Şerif Ali b.Fevzî Sandaka1-zade Bursavî Tilmizi, 1963. Mf1994 A 3909.
} 


\section{Müfíd ${ }^{5}$}

Müfîd'de şerh edilen metin harekeli değildir. Abdî Paşa, bu nedenle ana metinde yer alan her kelimenin nerdeyse okunuşunu vermiştir. Noktalı harflere mи 'ceme noktasız harflere mühmele demiştir. Bazen yanlış okumalara ve yanlış anlamalara imkân vermemek için kelimenin kalıbını okunuşu ile birlikte vermektedir.

şîn-i mu'cemenü̃ñ ve nûnûñ kesri ile (Müfîd, 3b).

hha-yı mühmelenün fethiyle ve dâl-ı mühmelenün şeddesiyle (Müfîd, 3a).

fermân, fânuñ fethiyle ve râ-yı mühmelenüñ sükûnıyla emr ma 'nâsınadur (Müfîd, 3b).

kahreş, şîn żamîrdür. Hudâ'ya râci 'dür, mâ-kabli râ-yl mühmele meftûha okunmak lâzım. (Müfîd, 4b).

Bazı kelimelerin harlerinin okunuşlarının yanı sıra Arap gramer kurallarına göre veznini ve örnek kelimeyi vererek kelimenin o şekilde okunmasına dikkat çeker:

Hamd, hâa-yl mühmelenün fethiyle ve mîmüñ sükûnıyla 'alime bâbından maṣdardur Müfîd, 2b).

Bazı kelimelerin vezin ve kafiye gereği tahfif, sükûn ve şeddeli/şeddesiz okunması gerektiğini ifade eder:

Lâkin kâhîce sâkin de oḳunur, żârûret-i vezn içün ammâ nâdirdür (Müfîd, 4b).

ol yânuñ ḥazflyla ișbâtı da câ'iz meger żarûret-i vezn ü ḳafiye ola (Müfîd, 4b).

Bazı kelimelerin Arapçada ve Farsçada farklı okunduğunu dile getirmektedir. İki dilde yazılışları birbirine benzeyen bazı kelimelerin, bir harfteki ses değişiklileri kelimelerin birbirinden farklı anlam değişiklikleri göstermesine neden olabilir.. "Kaf-1 Acemi: g § / Kaf-1 Arabi: k ك/Bā-yı Acemi: p ب/ Bā-yı Arabi: b ب/Cim-i Acemi: c ع / Cim-i Arabi: c ج/ Zā-y1 Acemi: j j” bu harfler Arapça ve Farsçaya göre ses ve anlam değişikliğine uğrarlar.

Küned, kâf-ı 'Arabînüñ dammıyla (Müfîd, 9b).

kâf-ı meftûha 'Acemîdür (Müfîd, 9b).

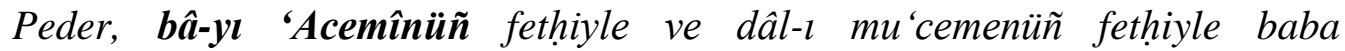
ma'nâsinadur (Müfî̀d 13a).

Bursevî ve Abdî Paşa'nın bazı kelimeleri farklı okumuşlardır.

“birehne” bâ-yı muvaḥḥadenüñ kesriyle (Bursevî, 14a).

“bürehne” bânuñ ḍammıla ve fethiyle ve râ-yı mühmelenüñ fethịle çıplaḳ ma'nâsinadur (Müfîd, 11a).

\section{Kelimelerin Anlamı}

\section{Bursevî}

Bursevî, kelimelerin gerçek anlamlarını vereceği zaman ma 'nâ-yı luġavîsi, bî-hasebi'lma'nâ ve ma'nâsınadur ifadelerini kullanır. Kelimenin metinde ortaya çıkan anlamını vereceği

\footnotetext{
5 Bu çalışmada Müfîd'in DİB Yazmalar Kitaplığının 004371 numarada yer alan yazması kullanılmıştır. https://yazmaeserler.diyanet.gov.tr/resource?itemId=10389\&dkymId=60453 E.T: 05.11.2020
} 
zaman bu cihetden, ez-cümle, burada murâd... dah̆ı dirler, el-hâṣıl, ma 'nâ eger kalb ile olursa tecevvüzi, mecâzen ve burada gibi ifadeleri kullanmıştır.

Dekâ'iḳ'de gelür ki 'Arab lâyı didügi yerde Türk yaraşur 'Acem şâyed dir ihtimâl vardur diyecek yerde mecâzen lisân-ı Türkî̀'de yarar didükleri gibi lisân-ı Fârsî'de şâyed dirler (Bûrsevi, 87b).

Rây-ı âb dirler 'Arab vechde itdigü tecevvüzi 'Acem rûyda ve Türk yüzde ider (Bursevî 143a).

Nevâșî nâșiyenüñ cem 'idür ki mukaddemü'r-re’sdür burada murâd ol mahalde sâbit olan șaçdur şa'r gibi. (Bursevî, 34a).

Şarihin kelimelere kendince anlam verdiği yerlerde olmuştur. Bu özel tasarruflar da $b u$ fakire zahir oldu ifadesini kullanmıştır.

Bu faḳ̂re zâhir olan budur ki de lafẓı dah̆ dene murahnhamdur pes hem dah̆ ma 'nâsına maḥmûldür (Bursevî, 9b-10a).

Bazı kelimelerin anlamlarını zıddıyla açıklamıştır.

Nîk, eyüdür mukâbili beddür ki yaramazdur zişt çirkindür mukâbili nîkîdur burada nîk kaṭı ma 'nâsınadur. sahnt ziş̧ gibi nitekim Türkîde dahı ı müsta 'meldür ki eyü çirkin ve eyü bed nesnedür dirler ḳatı çirkin ve bed ma 'nâsına (Bursevî, 131b-132a).

deryâ ḳara muḳâbilidür (Bursevî, 7a).

noḳsân kemâlüñ zıdddıdur (Bursevî, 55a).

Bazı kelimelerin kaç anlamı varsa onları beraberinde söylemiştir.

Müşt yumruk ve avuç ma 'nâlarına gelür (Bursevî, 2b).

Bazen kelime açıklarken doğrudan anlamını yerler de vardır.

Dâduñ virmekdür (Bursevî, 2b) .

Bursevî, bazen ana metinde yer almayan kelimelerin anlamlarını da açıklamıştır. Arapça ve Farsça kelimelerin Türkçe karşılığını verirken bu Türkçe kelimelerin de manalarını izah ettiği yerler olmuştur. Bu durum Türkçe kelimenin devri için arkaik olduğunu gösterebilir.

Tolu buzuñ bir nev'idür. Zîrâ semâdan kuvvet-i zemherîr ile müncemid nüzĥl ider buz ise zemînde olur ve tolunuñ bir vakte ih̆tișâșı yokdur belki eyyâm-ı șayfda dah̆ olur (Bursevî, 15a-15b).

Yarlı̀̇amak günâhdan geçmek ma 'nâsına (Bursevî, 32b).

Nân dışında aşağıda anlamını açıkladığı hiçbir kelime ana metinde geçmemektedir:

Nân etmekdür ki 'Arab hubz dir nânçîn tennûr içinden itmek çıkaracak âletdür

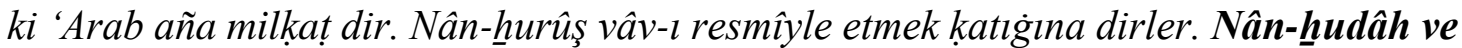
nâ-dâh etmekçi başıdur (Bursevî, 15b)

Günümüzde kullanılmayan bazı Türkçe tamlamaları Bursevî kendi döneminde tasavvufî manalarda kullanmıștır:

merd-i râh yol eri dimekdür ki murâd sâlik-i râh-ı Hakdur(Bursevî, 78b)

Bazen bir kelimenin Arapça, Farsça ve Türkçe karşılığını yerler de olmuştur. $\mathrm{Bu}$ durumda üç dilli bir sözlük hazırlıyormuş gibi davranmıştır: 
Sipâh leşkerdür ki 'Arab 'asker ve Türk çeri dir (Bursevî, 57a).

Türk Tañrl didügine 'Arab Allâh ve ehl-i Fürs Hudâ ve Rûm Esniyâ ve Ermenî Isfâh ve Efrenc Kerîtor ve Habeş Vâk dirler (Bursevî, 1b).

Farsça bir kelimenin anlamını yine Türkçeleşmiş başka bir Farsça kelime ile aktardığı yerlerde vardır:

Bîmâr, hastedür ki Türk șayru dir (Bursevî, 47a).

Arapça kelimeyi yine Arapça kelimelerle açıklamıştır:

Zufer șured vezni üzerine esed ü şücâ' ve bahr ma'nâlarına gelür (Bursevî, 30b).

Arapça kelimeyi Farsça kelime ile açıkladığı yerler de vardır.

hâmûş epsem dimekdür (Bursevî, 46b).

Bazı kelimelerin anlamını vermeden önce onların etimolojisini yapmıştır. Etimolojisini yaptığı kelimeler Arapça ve Farsçadır:

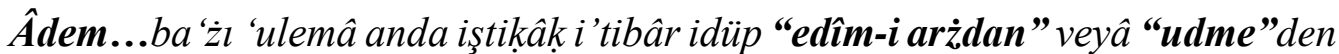
veyâ gayridan ahz eyledi. "Edîm” vech-i arżdur zîrâ türâb-ı Âdem vech-i arżdan me'hnuzzdur. "Udme" gendüm-gûndur ki 'Arap sümirat dahl dirler ve hilye-yi Nebeviyye'de esmerü'l-levn dinildügi evșâf-ı memdûhadandur ki beyâż nev'en siyâha mâ'il dimekdür tâ ki âyîne-yi İlâhî ola fe-efhemu velâkin gâh olur ki iştikâk i'tibâr olınmasa dah̆ iki lügatde tevâfuk bulunur. İdrîs'de kesret-i ders oldiğ l gibi ve İbrâhîm așlında Ebrâhâmdur ki Ebu Rahîm dimekdür (Bursevî 2b-3a).

Destere aṣlında dest-i erredür el bıçğısı ma 'nâsına (Bursevî, 10b).

Bazı kelimelerin nasıl anlam kazandıklarını anlattığı yerler vardır:

Dầ a ‘̇âda yakmağlla olan nişân gerek insânda ve gerek hayvânda ya 'nî insâna def'-i maraż ve hayvâna yâ def'-i maraż veyâ nişân içün itdükleri tamġadur. Burada murâd harâret-i 'aşkdan dilde hâș̣l olan eșerdür lâlenüñ bag்rında olan dâg gibi (Bursevî, 81a).

Şevket 'Arabîdür şevk-ı dakîk ve șulbü'r-re's olan otdur ki diken dirler. Silâh mak̂ulelerinüñ uçlart sivri ve keskin olmaġıla silâhdan şevket ile ta 'bîr olunur ve şevketlü bu maḳ̂̂le silâh u esbâb u levâzıma kâdir olandur ki selâṭ̂n ü mülûkuñ elkâbındandur (Bursevî, 81b).

Önceden açıkladığı bir kelimenin anlamını açıklamayıp onun yerine bâlâda şerh olunmuşdur ve tafsili mürur itmiş ifadesini kullanarak önceki açıklamalarına gönderme yapar. Bazen de açıkladığı bir kelimeyi yeri geldiğinde defalarca açıklamamış gibi aynı bilgileri tekrar etmiştir:

bâk̂̀-yi müfredât dah̆ı bâlâda şerḥ olunmusdur (Bursevî, 44b).

pîşe șlfat ve kârdur tafșîli mürûr itmişdür (Bursevî, 73a).

Bazı kelimeleri açıklarken ansiklopedik bilgi verdiği yerler de olmuştur:

Deryâ yedidür ki Baḥr-ı Rûm ve Baḥr-ı Șakâlibe ve Bahr-ı Cürcân ve Bahr-ı Kulzum ve Bahrr-ı Fârs ve Bahr-l Șin ve Bahr-ı Hinddür ve bu mecmû'uñ mâddesi Bahr$l$ muhît didükleridür ki bütün arżı ihâța eylemişdür ve lisân-ı Yunânîde anuñ ismi okyânûsdur (Bursevî, 7a).

yılanuñ zehrinden gayrı ba'żı ahcâr u nebâtât dah̆ zehr-nâkdur elmâs gibi ki bir ḳırâtı âdemi ihlâk eyler ve semm-i helâhil gibi ki ol bir otdur ki Sind iḳlîminde 
Helâhil şehrinde biter tâze iken yirler żarar virmez ammâ gayrl iḳlîmde öldürür naḳl olunup șatılan kökidür (Bursevî, 62b).

Bazı kelime gruplarını da açıklamıştır.

ez-ser tâ be-ser bir ucdan bir uca dek dirler makṣ̂ud iḥ̂țadur (Bursevî, 41).

hasen'il-vech güzel yüzlü dimek (Bursevî, 82b).

Bazı kelime gruplarını anlamını açıkladığı kelimelerin zaman içerisinde geleneksel bir anlamda kullandığını ifade etmiştir. Bu durumda bi-ḥașebi'l-'örfdür kelime grubunu kullanmıştır. $17 a)$.

bi-ḥașebi’l-‘örfdür lṭlâk üzerine isti 'mâl olunsa şâhdan murâd sulțân olur (Bursevî

\section{Müfíd}

Abdî Paşa, kelimelerin gerçek anlamlarını söyleyeceği zaman lügat ve ma 'nâsınadur, terim anlamlarını vereceği zaman ıstılah, mecaz anlamları için bunda, lâkin bunda, bu mahalde ma 'nâsı ve mecazen ifadelerini kullanmıştır:

Hamd, ... lugatde muṭlak ögmeye dirler (Müfîd, 2b).

Lugatde muṭlak ögmeye dirler ammâ ıștılâhda şol șenâya dirler ki ta 'ẓ̂m ḳaṣd oluna (Müfîd, 2b).

Bu mahalde ma 'nâsı bir avuç dimekdür (Müfîd, 3b).

çeşm, bunda ümîd ma 'nâsınadur (Müfîd, 25b).

Dak daluñ fethiyle lugatde dögmege dirler ammâ bunda mecâzen işitdürmek ma 'nâsinadur (Müfîd, 29b).

Bazen kelimenin gerçek ve metinde ortaya çıkan manasını aynı zamanda verir:

Pâk, bâ-yı 'Acemînün fethiyle arı ma'nâsınadur lâkin bunda şerîk ü naẓ̂rden münezzeh dimekdür (Müfîd, 3a).

Bir kelimenin dört farklı manaya gediğini ifade ettiği yerler de vardır:

Demîdenden müştakdur, yel esmek ve âdem üfürmek ve nebâtât bitmek ve peydâ vü zâhir olmak ma'nâlarına gelür. Bunda peydâ vü zâhhir eyledi dimekdür (Müfîd, 4a). vermiştir:

Çok nadir bazı yerlerde açıkladığı kelimenin Arapçasını ve Türkçesini aynı anda

Ahen, elif-i memdûde ile ve hânuñ fethiyle ve nûnuñ sükûnıla demüre dirler, 'Arabîde hadîd dirler (Müfîd, 7a).

Bazı kelimelerin Farsçada ve Türkçede ortak kullandığını dile getirmiştir:

Pes bu mûm kelimesi Fârisîde ve Türkîde iştirâk üzere müsta 'mel olmuşdur (Müfîd, 7a).

Bazen uzun izahata girmenin münasip olmadığını düşünür. O konu hakkında bilgi almak isteyenlerin tarih kitaplarında tafsilatıyla yer aldığını oradan okuyabileceklerini dile getirmiştir:

Hażret-i Dâvud Peygamberüñ avucunda demürü mûm eyledi ya'nî mûm gibi mülâyim ve yumuşak eyledi. Nitekim demürü mübârek elleriyle yumuşadup zırh 
yapdukları meşhûrdur ve tevârîhde mufașșal mesțûrdur. Zikri burada münâsib degüldür (Müfîd, 7b).

Bazı kelimelerin birden fazla anlamını verip metnin içine bu anlamlardan en uygun anlam hangisi ise onu göstermiştir:

Demî, de yâ vahdet içündür ve dem nefes ve zamân ve sâ'at ma 'nâlarına gelür ammâ Bunda ekall-i zamândan 'ibâretdür ya 'nî azıcık zamânda dimekdür (Müfîd, 9b10a).

Abdî Paşa, çok nadir olarak bazı kelimelerin etimolojisini göstermiştir. Buradaki tavrı Farsça öğretiyor gibidir:

Çerâ, cîm-i 'Acemînün fethiyle ve kesriyle lugatda ma 'nâsı niçün dimekdür zîrâ bu kelime "çe" ile "râ"dan mürekkebdür. Ne içün oldugin zâhir oldı lâkin bu mahalde "çerâ"nuñ çîmi fetḥle oḳunmak lâzımdur (Müfîd, 10b-11a). vermiştir.

Abdî Paşa, bazen kelimelerle ilgili açıklama yapmadan onların metindeki anlamlarını

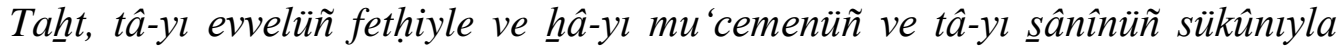
pâdişâhlar oturacak kürsîdür (Müfîd, 12a).

Abdî Paşa, kelimeleri anlamlandırırken teşbih ve istiare gibi edebî sanatlardan yararlanmıştır:

Talâk, ıșțllâh-l ehl-i şerî'atde 'avreti boşamagia dirler, lâkin bunda isti'âre tarîkiyle zikr olınmışdur. Zîrâ hażret-i şeyh dünyâyı 'avrete teşbîh idüp aña lâzım olan şeyleri dünyâya isbât itdi. Ya'nî müşebbehin bihüñ levâzımını müşebbehe isbât eyledi. Ma 'ânîde buña isti'âre-i tahyîliyye dirler (Müfîd, 36b-37a).

\section{Misra ve Beyitlerin Anlamı}

\section{Bursevî}

Beyitteki ve/veya mısradaki kelimelerin anlamlarını verdikten onların cümle içerisideki yerlerini belirttikten sonra mısra ve beyitlerin manasını aktarmıştır. Beyitte ve/veya mısrada açıklanan durum yeterli değilse yani metnin anlam katmanlarını verecekse o zaman el-ḥ̂șıl, pes ifadeleri ile açıklamasını derinleştirip sonuca bağlamıştır.

ma'nâ-yı beyt budur ki dostlar arasında mesrûr olup otur zîrâ dostlara karîb olmak ve aralarında bulunmak bâ 'is-i üns ü hużûr u sürûrdur ve eger 'akl-ı tâmmuñ var ise ve idrâk-i kâmil tutarsañ düşmenden ve dâ'iresinden ve șohbetinden dûr u ba'îd ol zîrâ anlardan dûr olmak sebeb-i râhat-ı dil ve nezdîk olmak mûcib-i keder-i muttașildur el-hâșıl dostân dâ'iresinde bulunmak bâg u bostân içinde olmak gibidür ki âdemün dimâğ pür-bûy-l üns ve kalbi dâhil-i bezm-i 'âlem-i kuds olur düsmenân miyânında olmak ise hâr-zâr içinde kalmak gibidür ki dâmen-i dil ve hâş̧iye-yi câme-yi hâtı̣r derîde olmakdan hâlî olmaz ve çesm-i cân rûy-ı elem görmekden çâre bulmaz ve dimişlerdür ki düsmenlerle zindegânî itmek hatâ vü ifsâd-ı 'ömr ve isrâf-ı sermâye-yi vücûddur (Bursevî, 60b).

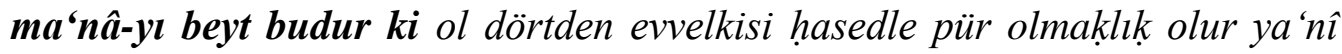
düşmeni olan kimsenüñ ni 'meti zâ'il olup kendine olduġı istemekdür bu ise fíl-hakîka küfrdür zîrâ Allahu te 'âlânuñ hükmine cehlden ve hikmete i'tirâzdandur ve bu hasedi geçdükden șonra ol dört hașletüñ ikincisi 'ucb didükleri șlfatdur ki 'Acem andan hodbînlik ve Türk kendin göricilik ile ta 'bîr ider ve kendin görmek Hakka nisyândan ve tevfikıın 'adem-i mülâhazadandur ve bunda şấibe-yi i'tizâl vardur ya'nî tâ'ife-yi mu'tezile 'abd ef'âlini kendi halk ider diyüp hallâkı nisyân itdükleri gibi mu'cib be- 
nefse ve be-râ 'iyye dạh ef'âlini kendine iżâfet itmiş olur tevfîk ü tertîb-i esbâb ise hakdandur pes te 'sîr ü halk Hakdan olıcak gayra nazar itmek gerek kendi nefsine ve gerek âhıre bâtılldur (Bursevî, 132b).

Beyitlerin şerhinde çoğu zaman tasavvufî yorumlar yapmıştır:

Halkdan berî olmak Haḳka ittiṣâldür (Bursevî, 43b).

Bursevî, misra ve beyitleri şerh ettiği bölümde yeri gelince deyim, atasözü, kelâm-1 kibardan yararlanmış. Şerhini bazen bu söz varlıklarıyla anlatmıştır. Atasözlerini aktarırken daha çok meşhurdur ki, meseldür ki / fi'l-mesel ve Türk dah̆l... dir ifadelerini kullanmıștır. Bazen hiçbir ifade kullanmadan da atasözünü aktarmıştır:

Türk dahı göz açup yumunca geldi geçdi dir ‘̈̈mr ve devlet ve emșâli gibi (Bursevî, 15b).

Meşhûrdur ki söylerler dil birdür iki ḳulak bir söyle iki diñle (Bursevî 50a).

Meseldür ki dirler üzüm üzüme göre kararır (Bursevî, 55b).

Kesemedigü̃̃ eli öp (Bursevî, 60a). vermiștir:

Bursevî şerhinde çok sayıda deyim vardır. Bunlardan bazılarının Türkçe anlamını

A $\dot{g} z u \tilde{n} \iota$ mühürlemek ve sükûnetle mukayyed ḳlmak (Bursevî, 45a).

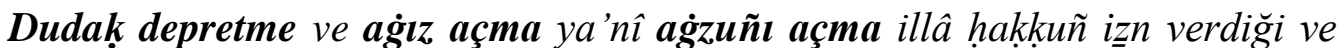
şer'üñ ruhssat gösterdiği vechle güşâde ḳl yohssa nehy itdigi ve buyurmadiğ lisana getürme (Bursevî, 46a).

Yeri geldiğinde açıklamalarını Farsça deyim ve atasözleri ile zenginleştirmiştir.

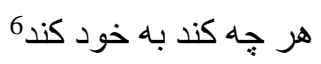

Her çe küned be-hod küned (Bursevî, 43a).

Bursevî şerhini yazarken Kur'an-1 Kerim'den çokça yararlanmış, neredeyse her kavram ve ibare için Kur'an'dan dayanak getirmiştir:

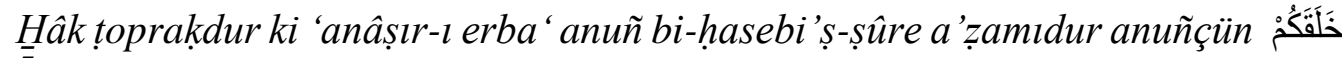
مِنْ تُرَابٍ

\section{Müfíd}

Abdî Paşa, mısraları tek tek ele almamıştır. O, beyitleri şerh etmiştir. Beyitleri şerh etmeden önce mahșûll-i beyt ifadesini kulanmıştır. Beyitleri daha çok tercüme edip açıklamalarını derinleştirmemiştir. Çok nadir olarak açıklamalarını derinleştirmek istediğinde hâṣ̂ll-ı kelâm ifadesini kullanmış. Sonra açıklamalarına devam etmiştir.

Hâsṣl-ı kelâm ol Resûl-i Ekrem șallallÀhu 'aleyhi ve sellem Hażretleri cismânî bu tokuz kât eflâkdan geçüp tâ 'arș-ı a zạama vâșl oldı. Nitekim ḳıșa ile mi 'râc gün gibi zâhir ve 'ayân ve ma 'lûm-ı 'âlemiyân-ı mu'temed ehl-i îmândur nebîler dah̆ velîler ol Resûl-i Ekremüñ muhtâcıdur (Müfîd, 17a).

Abdî Paşa bazı açıklamalarında birtakım deyimler kullanmıştır.

\footnotetext{
${ }^{6}$ Kim ne yaparsa kendine yapar.

7 “Sizi topraktan yaratt1." Mü’min 40/67.
} 
Başına ḳakasun (Müfîd, 21a).

Yüzlerinün karalugìdur (Müfîd, 23a).

Yolımı urdı (Müfîd, 25b).

Yüzin döndürsün (Müfîd, 27a).

Göñli yara eyledi (Müfîd, 27b).

Lisânuñı baġla (Müfîd, 28a).

Bazı yerlerde deyimlerin anlamını vermiştir. Bu durumda "ya' $n \hat{\imath}$ ” ifadesini kullanmıştır:

başı çekici 'inâd üzre (Müfîd, 27a).

kulaġını bur, ya 'nî te'dîb eyle (Müfîd, 27a).

Yüri var diliñi ag்zında maḥbûs tut ya 'nî habs u żabt eyle. Hâṣ̂ll-ı kelâm kimseye söz söyleme dimekdür (Müfîd, 30b).

Ol pâdişâhuñ içün bir baş üzerine yüz cân oynarlar ya 'nî pâdişâhlarınuñ yolına cânlarını ve başlarını fedâ iderler dimekdür (Müfîd, 33b).

Düşmene yol virme ya 'nî düşmeni yakîniñe ve ḳoñşulugiuña götürme (Müfîd, 34b).

Atasözü: Her kimse ne iderse kendüye ider(Müfîd, 27b).

Abdî Paşa, açıklamalarında Kur'an Kerim'den ayetlere de yer vermiştir. Ana metinde geçen bir ifadeyi anlatacağı zaman telmih ve âyetinün mażmûn-ı şerîfine telmiḩür ifadesini kullanmıştır. Metin ile ilgili yaptığı açıklamalara kanıt olarak Kur'an-1 Kerim'den ayet getireceği zaman Hażret-i Hak Kur'ân-ı 'Az'iminde buyurmuşdur ifadesini kullanmıştır.

Abdî Paşa bir yerde mahsul-i beyitte, beytin anlamını açıkladıktan sonra ansiklopedik bir açıklamada bulunmuştur. Bunu yapacağını göstermek için de ma 'lûm ola ki ifadesini kullanmıştır:

Ma'lûm ola ki mežheb-i meşhûr dörtdür, evvelki Hanîfidür, ikinci Şâfì'dür, üçüncü Mâlikîdür, dördüncü Aḥmed Hanbelîdür. Bu dört mezheb de hakdur. Lâkin

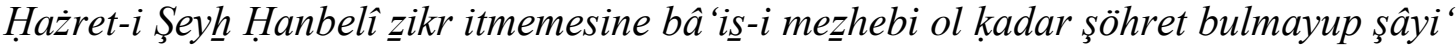
olmaduġına binâen olmakdur. Allâhu a lem hakîkatehu

\section{Yapısal Özellikler}

Bursevî’nin şerhinin önemi bir yönü de harflerden, kelimelere ve cümleye kadar tek tek her unsuru yapısal yönden incelemesidir. Bursevî, Arap gramer özelliklerine göre kelimeleri, tamlamaları ve cümleleri irdelemiștir.

\section{Kelimeler} kullanmıştır.

Bursevî kelime kökeni için asl ifadesini; türetilmiş kelime için müştâk kelimelerini

Destere aṣlında dest-i erredür el bıçg்ısı ma 'nâsına (Bursevî, 10b).

Âzâr âzârden laf̧̣ından müştaḳdur (Bursevî, 24b).

\section{Edâtlar}

Yalnız başına bir anlamı olmayan isim ve fiillerle kullanıldığında onlara mana katan kelimelere edât denir (Çörtü, 2010, s. 91). Bursevî, bazen edâta harf dediği yerler de vardır.

"b̂̂̀" lafż̀ edât-ı nefydür (Bursevî, 1b). 
"tâ" burada edât-ı ta 'lîldür lâm-ı cârre ma 'nâsına (Bursevî, 4a).

"râ" lâm-l cârre ma 'nâsinadur ki tahsșị̂ ifâde ider ve sûyda harf-i cerr mahızûfdur (Bursevî, 53a).

“çün” harf-i şarț (Bursevî, 88b).

Abdî Paşa da edat ve harf kelimelerini kullanmıştır:

Mer mîmün fethiyle ve rânuñ sükûniyle edât-ı șlladur (Müfîd, 50b).

yâ harf-l 'atfdur (Müfîd, 64a).

$\dot{I} \operatorname{sim}$

Zamana ve bir şahsa bağlı kalmadan kendi başına bir manası olan kelimelerdir. İsmin içerisinde harf ve fiil dışındaki bütün sözcük türleri girmektedir.

Nûh ism-i 'Acemîdür (Bursevî, 3b).

"-zâr" ism-i câmid olıcak "-lik" ma "nâsın ifâde ider (Bursevî, 4b).

în șıfat (Bursevî, 52b).

bu şîne ̇̇amîr-i ġâyib-i müfred dirler (Bursevî, 56b).

ey kelimesinüñ münâdîsidür (Bursevî, 72b).

der aña zarfdur (Bursevî, 88b).

Abdî Paşa sayı isimlerine ism-i 'aded tabirini kullanmıştır:

Evvelki ki ismdür kim ma 'nâsını (Müfî̀, 64b).

ism-i 'adeddür iki ma 'nâsınadur (Müfîd, 64b).

Fiil

Şahıs ve zamanla beraber iş, oluş, durum bildiren kelimelerdir. Bursevî, çekimli fiile $f i$ ' derken zaman ve şahıs olmayan fiile mastar demektedir. Şimdiki zaman için mużâri ‘; geçmiş zaman için de $m a z i$ ' demiştir.

fi 'l-i mużâri’-i g̀âyibdür maṣdarı gerdîdendür (Bursevî, 88a).

kâf-ı 'Acemî ile fí 'l-i mầî̀-yi muhâțabdur şüdî ma 'nâsınadur (Bursevî, 86a).

Geçişsiz fiil için lâzım ifadesini kullanmıştır.

Maṣdarı kerdânîdendür, bir hâlden bir hâle döndürmek șayrûret ma 'nâsına lâzımı kerdîdendür dönmek ma 'nâsına (Bursevî, 40b).

\section{Müfid}

Abdî Paşa, çekimli fiile $f{ }^{\prime} l$ derken zaman ve şahıs olmayan fiile mastar demektedir. Şimdiki zaman için mużâri '; geçmiş zaman için mazi ' demiştir.

fi 'l-i mâäi'-i müfred-i ġâyibdür (Müfîd, 37a).

fi'l-i mużâri'den șoñra vâki 'olmaġlla maṣdar ma 'nâsına olur(Müfîd, 37a).

Geçişsiz fiile "lâzım” fiil demiştir.

bâyed fi 'l-i mużâri 'dür, lâzımdur(Müfîd, 37a). 


\section{Tamlama} kullanmıştır:

Bursevî, isim tamlaması için izafet; sıfat tamlaması için vasf-ı terkîb ifadesini dürri 'Adene iżâfet ḳldı (Bursevî, 49a).

şefâ 'at-h̆v âh vașf-ı terkîbîdür şefâ' at dileyici ma 'nâsına (Bursevî, 36b).

Abdî Paşa sıfat tamlaması için vașf-ı terkîbî̀ yi kullanır:

Nîk-baht, vașf-ı terkîbîdür, eyü țâli'li sa 'âdetlü dimekdür (Müfîd, 36b).

\section{Cümle}

Bursevî, özneye mübtedâ ve fâ 'il, yükleme fi'l ve haber, nesneye mefûl demiştir.

herkesî mübtedâ (Bursevî, 48b).

ba 'de’l-cümle mübtedâya haberdür (Bursevî, 48b).

her çi ikinci mî-şevedün fấili ve gâret mef'âli (Bursevî, 48b).

Abdî Paşa Müfîd'de özneye mübtedâ, yükleme fi 'l ve haber nesneye mef'ul denmiştir.

Hest şeytân mukaddem haber-i düşmenet mu 'ahhhar mübtedâdur (Müfîd, 7b).

Mișrâ'-l șânîde olan gerd ca'le ma 'nâsınadur, ef'âl-i kulûbdandur, iki mef'ûle ta 'diye ider. Ahen mef' ûl-i evveli ve mûm mef' $\hat{u} l-i$ sânîsidür (Müfî̀, 7b).

\section{Nüsha Farklılıkları}

Bursevî, Pendnameyi şerh ederken elinin altında birden fazla nüsha olduğunu ve bu nüshaları yeri geldiğinde metin şerhinde kullandığını ifade etmiştir.

vâv 'âtıfdur ân diger-râ yerine ba' zı nüshada dîgerî-râ düşmüşdür (Bursevî, 10b)

ber pisterî ki kimhâa est dimekdür ve bundan ber lafżı ki isti'lâ içündür müte'allıḳı ma'lûm oldı ve $\boldsymbol{b} \boldsymbol{a}^{\boldsymbol{6}} \boldsymbol{z} \iota$ nüsh $\boldsymbol{h} \boldsymbol{a d a}$ yâ yoḳdur (Bursevî, 14b).

Her ki û terk-i ten âsânî küned

Pes hilâf-ı nefs-i sultânî küned

bu beyt gayrı nüshalarda yoḳdur bizüm yedimizde olan bir nüsha-yı 'âtîkada bulundı (Bursevî, 80b).

nüsha-yı uhrâya göre (Bursevî, 91a).

Abdî Paşa, bazı yerlerde nüsha farklılığından bahsetmiştir. Verdiği nüsha farklılığını da tercüme etmiştir.

Ba'żı nüshada mıșrâ'-ı șânî böyle vâkịi olmuşdur

Gîr kûş bâşed 'ayb-ra pâdişâh

ma 'nâsı pâdişâha 'ayb olur, kulak țut, diñle bu nașị̂ati dimekdür (Müfîd, 32a-32b).

ba'‘் nüshada genc vâki 'dür (Müfîd, 33a).

\section{Eleştiriler}

Bursevî, eseri şerh ederken kendince doğru bulduğu yerlerle ilgili olarak başka şarihlerin yaptıkları yorumları hatalı bulup eleştirmiştir. 
Zer gümüşe dah̆ şâmildür diyen hatâa itdi (Bursevî, 92a).

Bursevî, yeri geldiğinde şerh ettiği metni de eleştirmiştir.

Nidâyı taḳdîm itse evveli olurdı zîrâ hem vezne halel gelmez ve hem nev'-i kelâm yerini bulurdl. (Bursevî, 54b).

Yeri geldiğinde açıklamaları için kaynak olarak kullandığı İbn-i Kemâl'i eleştirmiştir.

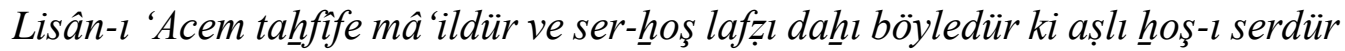

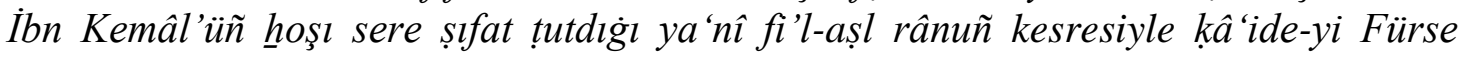
munhâlifdür (Bursevî, 86b).

Abdî Paşa da Müfîd'de kendisinden önce Pendnameyi şerh edenleri eleştirmiştir.

Amma bu hemze ba ‘żllar hitâb içündür ve vahdet içün țutmuşlar amma didikleri ma 'nâ luġatlarda yoḳdur. Zâhir budur ki kendi yanlarından söylemişdür (Müfîd, 6a).

Abdî Paşa, eleştiri yaptığı gibi Şem'î'nin verdiği bir hükmü de beğenmiştir.

Şem 'î merhûm mıșra'-l șânînün ma 'nâsında dakka ve gamzdan ötüri hak sözi söyleme ya 'nî söz hak ise de çok söylemek gamza îcâb itdi, anı söyleme deyü ta bîr itmiş yerindedür (Müfîd, 30a).

\section{Dilbilgisi İlgili Bilgi Verilmesi}

Bursevî, metni şerh ederken yer yer üç dil ile ilgili birtakım dilbilgisi kuralları anlatmıştır. Dilbilgisi için Bursevî kavâ id ifadesini kullanmıştır. Açıkladığı dilbilgisi konuları daha çok üç dilin gramer karşılaştırılması doğrultusundadır.

Hâyı zâya kalb idüp endâzed ve endâzende dirler zîrâ ḳavâid-i Fürsdendür (Bursevî, 5a).

Fârsîde 'Arabîdeki gibi șıfat ve mevșûf arasında muṭâbaḳat şarț degildür (Bursevî, 76b).

Fârsîde ef'âl taf̣̣̂l șî̀ंası yokdur ol ma 'nâyı terkîb ile edâ iderler meșelâ eksiklikde ve artuklukda bir nesnenün fadlln beyân itseler kem-ter ve efzûn-ter dirler (Bursevî, 87a).

Farsça kelime yapımından bahsedip gramer bilgisi aktarmıştır. Bu durumda bazen ma 'lûm ola ki ifadesini kullanmıştır.

Ârâyiş bezeyiş dimek olur ki ism-i mașdardur ammâ bezek ya 'nî zînet ma 'nâsına şâyi'dür ma 'lûm ola ki emr-i mücerredün âhırına lâhılk olan şîn 'alâmet-i ism-i mașdardur dâniş ve bîneş ve reviş ve emșâli gibi bu şînün mâ-kabli kaț'en meksûr okunur ve żamîr-i ĝ̀âib olan șîn cânes gibi ve żamîr mef' ûle dîdemeş gibi bunlaruñ mâkablleri meftûh oḳunur ve ba 'ż țâ ife kesr ile dah̆ telaffuz itmişlerdür (Bursevî, 77a).

Abdî Paşa, ma 'lum ola ki ifadesini kullandıktan sonra dilbilgisi ile ilgili bilgi vermiştir.

Ma'lûm ola ki âhirinde hâ-yı resmî olan kelimelerün âhirlerine yâ-yı vaḥdet iktiżâ etse kitâbet olunmaz ancak hemze ile iktifâ olunur (Müfîd, 9a).

Farsça fiilerle ilgili bilgi vermesi:

Dâdeñden müştakdur. Kẩ ide-i külliyedür ki Farisîde müââderüñ âhiri nûn olur, nûnuñ mâ-ḳabli tâ olur dânisten gibi yâhûd dâl olur dâden gibi. İmdi bunlardan bunuñ gibi mașdarlardan ancak fi 'l-i mâzi ile ism-i mef'ûl müştak olur ammâ şol mașdar ki âhiri nûn, nûnuñ mâ-ḳabli dâl, dâluñ mâ-ḳabli yâ ola şenîden gibi şîn-i mucemenüñ ve 
nûnuñ kesriyle ve yânuñ șükûnıyla ve dâluñ fethiyle ve nûnuñ șükûnıyla mașdardur (Müfîd, 3a).

Yâ harfini işlevlerini anlatmıştır:

ma 'lûm ol ki bu lisân-ı Fârisîde yâ sâkin esmâ ve ef'âlün âhirine lâhılk olur. Bir nice ma "nâya gelür. "Yâ" vahdet içün olur. "Yâ" tenkîr içün olur. "Yâ" nisbetiyye olur. "Yâ" mașdariyye olur ya hit tâb içün olur. Ba 'żlar bu "yâ" hițâbı ef'âl âhiründe isti "mâl itdiler. Bu mezkûr olan "yâ" esmâya mülhak olandur ammâ ef âle mülhak olan "ya" ekser hikâye içün olur ve "yâ"-yı baține ve iżâfiye dahı vardur. Hatta Kemâl Paşazâde bu żikr olunan "yâ"ları şu 'belendirdin yigirmi dürlü ma 'nâsını murâd eylemiş. Lâkin tâlib-i Fârisî olan kimesnelere ol kadar fâ'idesi olmaduġından taḥrîrüñ ihtiyâr itmedük (Müfîd, 4b).

Ki harfinin manalarını anlatmıştır:

$K i$, kâf-l 'Arabînün kesriyle ve hâ-yl resmîyle harfle isim mâbeyninde müşterekdür. Pes eger ism murâd olunursa bir şaḥ̦-ı żevi'l- 'ukuldan ibâretdür, Kim ma'nâsına. Kâf-l 'Arabînüñ kesriyle mimüñ sükûniyla ve ger harf-i murâd olunursa dört ma 'nâya gelür. Yâ harf-i râbt-ı șlfat olur, yâ beyân içün olur, yâ ta 'lîl içün olur, yâ men tafżiliyye ma'nâsına olur (Müfîd, 3a).

Bunların dışında "ber" ve "râ" kelimelerinin birkaç anlamlarının olduğudur. Mahallinde beyân olunacağını da söyleyip konu bahsi geldiğinde açıklamalarını yapmıştır.

Abdî Paşa'nın dilbilgisi ile ilgili tartışmalı bir durum olduğunda Sûdî Efendî’nin görüşünü benimsediğini dile getirmiştir.

Sûdî rahmetullâhi 'aleyh ancak evâhir-i esmâya manhṣ̂șdur didi. Pes tahkîk budur ki esmâya mahșûșdur (Müfîd, 23b).

\section{Açıklamalarda Örnek Beyit Verilmesi:}

Bursevî, bazı şairlerin beyitlerini kendi açıklamaları için örnek tutmuştur.

Zeyneb şâ ire dimişdür beyt:

Zeyneb ḳo meyli zînet-i dünyâya zen gibi

Merdâne-vâr sâde dil ol terk-i zîver it (Bursevî, 63a).

Müfîd'de de açıklamalar için örnek beyitler verilmiştir.

Nitekim Şeyh Sa'dînün bu beytinde zâhhirdür, beyt:

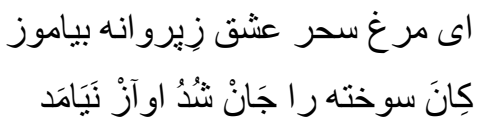

Ey murg- seher 'aşk zi-pervâne biyâmûz

K'ân sûhte-râ cân şüd avâz neyâmed ${ }^{8}$

\section{Şerhlerde Kaynak Eser Kullanımı}

Bursevî, eseri şerh ederken tefsirden sözlüğe kadar birçok kaynak eser kullanmıştır.

Keşşâf, İbn Kemâlüñ Dekâ'ikı, Lüğat-ı Karahiṣ̂̂rî, Lug்at-i Ni'metullâh, İmâmı Kurțib̂̀, Halîmî”, Şâhidî Lügatinde, Muhammediyye, Imâm Beyhaḳ̂̀ Ezâhîr nâm kitâbda, Resehât nâm kitâbda, Îmâm Râgı̀b'uñ Müfredâtında muṣarrahdur.

\footnotetext{
${ }^{8}$ Ey seher kuşu (bülbül), aşkı pervaneden öğren, zira o canını yaktı ama ondan hiç bağırıp çağırma gelmedi.
} 
Kendi eserine de gönderme yapmıştır.

Nitekim tefsîrimiz Rûhư'l-Beyânda mufașșaldur (Bursevî, 17b).

Bir yerde kitabî değil sözlü kaynak kullandığını ifade etmiştir.

Gerdî kâf-l 'Acemî ile meşhûrdur ve Fârsiyyü'l-aṣl olanlara su'âl olunduḳda bu vechile cevâb virmişlerdür maṣdarl gerdîdendür ki dönmekdür (Bursevî, 81b).

Elindeki kaynakların yetersizliği üzerinde durmuştur.

Nitekim dirler çok yasa az yaşa șoñı ölümdür ve burada baṭn-ı gâr bir ḳıșsaya telmîh olmak iḥtimâli dah̆ vardur velâkin bizde olan kütübde bulunmadı ve bu beyt dah̆ ekser-i nüsahda yokdur (Bursevî, 82b).

Abdî Paşa kaynakları daha çok dilbilgisi ile ilgili bilgi verdiğinde kullanmıştır.

Tevarih, Sûdî Efendi'nin şerhleri, Kemâl Paşazade, Dakâyılku'l-Hakâyık, Ni 'metu'llâh, Şâhidi lugiati, Tuhfetü's-Seniyye șâhibi ve Halîmî ve Lâmî' ve dahı sâ'ir lugiat șâhiblerüñ (Müfîd, 23a-23b)

Sûdî Efendi’nin Gülistân şerhini okuduğunu ve beğendiğini beyan etmiştir:

Nûşîrevân-ı 'Âdil hikâyesinde vâki ' olan beytüñ şerḥinde şâżumânı ta 'rîf itdikde şârih Sûdî rahmetullâhi 'aleyh bu mezkkûr kấ 'ide-i külliyen bir hoş beyân eylemişdür (Müfîd, 15b).

\section{Sonuç}

Abdurrahmân Abdî Paşa şerh etmeye kelimedeki harflerin okunuşu ile başlamış, onların nasıl okunacağını göstermiştir. Bursevî şerhinde bunun yerine Farsça metni harekelendirmeyi tercih etmiştir. Bazı durumlarda birtakım kelimelerin okunuşunu gösterdiği yerler de olmuştur.

Abdî Paşa, kelimelerin gramer özellikleri ve cümledeki yerlerini gösterirken Bursevî şerh etmeye önceleri kelimenin tamlama ve cümle içindeki yerini söylemekle başlamış bir müddet sonra bazı beyitleri nesre çevirip sonra îrâb yapmıştır. Bu özellik düzenli değildir. Arada birkaç beyti Arapça nesre çevirmiştir. Nesre çeviriyi beyitteki Farsça kelimeleri Türkçe cümle yapısı içinde her bir ögeyi yerli yerlerine koymasıdır. Bu durum Türkçeye tercüme değildir.

Bursevî, kelimeden önce sözcüğe gelen ve ona anlam katan ek varsa bu ekin anlamını vermekle açıklamasına başlamış, sonra dilde kullanılan buna benzer bir ek varsa onunla mana olarak karşılaştırıp örnekleme yoluna gitmiştir. Abdurrahman Abdî Paşa, ekin anlamı yerine onun görevini söyleyip açıklamalara girmemiştir. Bursevî’nin yaptığı gibi örneklemelere ve dilde eş değerliliği olan eklere de yer vermemiştir.

Abdurrahman Abdî Paşa ve Bursevî gramer açıklamalarında genelde birbirileriyle aynı eksende açıklamalar yapmışlardır. Şerhlerinde bu konuda birbirleriyle çelişkili çok farklı açıklamalar yer almamıştır. Çok nadir de olsa şarihlerin bazı farklı açıklamaları olmuştur. İki şarih de Farsça işaret zamiri olan ân kelimesinin gramer özelliğini anlatırken farklı yolları tercih etmişlerdir. Bursevî’ye göre ân kelimesi üçüncü tekil $o$ kişi zamiridir. Gerekli olmamasına karşın çoğulunun da ne olduğunu söylemiştir. Bir de $b u$ anlamına gelen Farsça în kelimesini aktarmıştır. Sonra bu kişi zamirinin müsâhama (kusuru görmezden gelerek) ile işaret zamiri manasında kullanılmasını doğru bulmamaktadır. Buna da Arapça gramer kurallarına göre delil getirmiştir. Abdurrahman Abdî Paşa'ya göre ise ân ism-i işarettir. $\mathrm{O}$ da kendince Arapçadan delil getirmiştir. Ve o kelimenin tamlanan olarak gramerdeki yerini göstermiştir İkisi de gramer olarak aynı tanımlamayı kullanırken getirdikleri delil yönüyle birbirlerinden farklılık 
göstermektedirler. Bursevî, ism-i işaret dediğinde kişi ve dönüşlük zamirini anlarken; Abdî Paşa, işaret zamirini anlamaktadır.

Şarihler, şerh ettikleri metinlerdeki anlamın ortaya çıkması için kelimelerin sözlük yani lugavi anlamının yanı sıra metnin bağlamından yola çıkarak nasıl mecaza düştügünü bazen sözlükler yardımıyla bazen kendi bilgi ve deneyimlerini kullanarak açıklamışlardır. Bursevî bazen de halkın bu konuda benzer durumlarda neyi nasıl kullandığını göstererek açıklamıştır. Şarihlerin kelimelere mana vermelerinde kullandıkları kaynaklar açısından birbirlerinden farklılıklara sahip oldukları gözlenmiştir.

Abdurrahman Abdî Paşa, $\underline{H} u d \hat{a}$ kelimesinin sadece Allah'a has olduğunu ve başka yerlerde kullanılmasının caiz olmadığını dile getirmiştir. Farsça olan bu kelimenin Türkçede karşılığının aslı Arapça olan Allah kelimesi ile karşılamıştır. Ona göre bu kelime Allah’tan başka kimse için kullanılmamalıdır.

Hudâ yâ ile ve yâsız zât-ı Bâriye 'alem-i hâșdur. 'Arabîde Allâh gibi Vâcibü'l-Vücûd ma'nâsına ve gayre iṭlâkı câ'iz degül eger Allâh'dan gayrlya bir kimesne Hudâ ițlâk eylese kâfir olur (Müfîd, 3a).

Bursevî ise Hudâ kelimesinin etimolojik tahlilini yapmışve bu kelimenin başka dillerdeki karşılığını dile getirmiştir. Türkçe Tanrı demektir diyerek anlamını söylemiştir. Bunun yanı sıra kelimenin Ermenice, Rumca, Efrenç ve Habeşçe karşılığını da dile getirmiştir. Abdurrahman Abdî Paşa Hudâ kelimesi ile ilgili Bursevî gibi bir açıklama yapmamıştır.

Anlam ile ilgili tespit edilen en önemli özelliklerden biri de anlamın çok katmanlı olduğu yerlerde Bursevî’nin derinlemesine izahata girmesidir. Abdî Paşa, kelimelerin anlamlarını mecaz anlamlar dâhil olmak üzere mananın derinliklerine inmeden verirken, Bursevî bu kelimelerin bir de irfânî boyutları ve halk arasındaki kullanımlarıyla kendi dönemi için arakaik olabilecek kelimelerle de vermiştir. (Çünkü Türkçe kelimelerin anlamlarını şerh metninde açıklaması bu kanıyı güçlendirmektedir.) Hatta şerhinde bazen Türkçe kelimeleri bile açıklamıştır. Türkçe kelimelerin tasavvufî̀ manaları üzerinde durmuştur. Abdî Paşa'nın müfîd adlı şerhinde Türkçe kelimelerin manası verilmemiş, Türkçe kelimelerin tasavvufî boyutu üzerinde hiç durulmamıştır.

Bursevî, mahsul-i beyt bölümünde beytin anlamını verdikten sonra ya'nî, hâsılı ve bunda diyerek anlamın diğer katmanlarını da ortaya koymuştur. Buna neden olan durum eğer kelimeden kaynaklanıyorsa, kelimenin anlam katmanlarına göre metnin o bölümü her manaya için tekrar açıklanma yoluna gidilmiştir. Eğer anlam katmanı sadece kelimenin anlamı ile ilgili değil de söz öbekleri ve kelimelerin diğer kelimelerle olan bağlantılarından ortaya çıkıyorsa şarih bunu özellikle belirterek açıkladığı bölümü bir kez daha şerh etmiştir. Burada o zaman şarih kendi dilindeki deyim, atasözleri ve söz öbeklerini verir. Bu açıklamayı yaparken verdiği sözvarlığını da açıkladığı yerler olmuştur. Bu derinlemesine yapılan açıklamalar daha çok tasavvufî manayı vermeye dönüktür. Bursevî burada üç dilin imkânlarını sonuna kadar kullanmıştır. Abdî Paşa'nın mahsul-i beyt bölümünde yaptığı açıklamaların birçoğu tercüme havası içinde olmuştur. Derin izahatlara gidilmemiştir.

Abdî Paşa, 16. yüzyılda yaşamış şarihlerimizden Sûdî Efendi’yi beğendiğini dile getirmiş, açıklamalarını da onun gibi daha çok gerçek ve mecaz boyutlarıyla yapmıştır. $\mathrm{O}$, da Sûdî Efendi gibi tasavvufî şerhe pek girmemiştir. Bu yönü ile de Bursevî’nin şerh anlayışından farklıdır.

İkisi de aynı dönemde yaşayan şarihler aynı esere farklı okuma, açıklama ve yorumlar getirerek Pendname'yi şerh etmişlerdir. Yapı ve anlam açısından birbirlerine benzeyen yerler olmasına karşın birbirlerinden çok farklı yerler de vardır. Anlamın ortaya çıkmasında kendilerince birer yöntem geliştiren bu şarihlerin Pendname şerhlerinde üç dilin sözvarlığı ve 
gramer bilgileri açısından da zengin birer kaynak olma özellikleri vardır. Şerhler, metinlere anlam vermede tercümelerden (çevirilerden) farklı olarak tek anlamı değil de eserin derinliklerinde yatan manaları da bulup çıkarmaları yönünden ayrılmaktadır.

\section{Kaynakça}

Akçay, G., (2013). Mustafa refía-berg-i dervîşân (karşılaştırmalı inceleme-metin). (Yayınlanmamış doktora tezi). Edrine: Trakya Üniversitesi Sosyal Bilimler Enstitüsü Türk Dili ve Edebiyatı Ana Bilim Dalı Türk Edebiyatı Bilim Dalı.

Çakıroğlu, T. O., (2008). İsmail Hakkı Bursevî'nin şerh-i pend-i attâr adlı eseri üzerine inceleme. Dil ve Edebiyat Araştırmalart. 11(5), 2020 tarihinde https://dergipark.org.tr/tr/download/article-file/714447 adresinden alınd1

Çakıroğlu, T. O., (2012). İsmail Hakkı Bursevî'nin "şerh-i pend-i attâr" (Attâr'ın pendnâmesi'nin açıklaması) adlı eseri üzerine bir inceleme ve attâr'ın pendnâme'si ile karşılaştırılması. (Yayınlanmamış doktora tezi). Ankara: Hacettepe Üniversitesi Sosyal Bilimler Enstitüsü Türk Dili ve Edebiyatı Anabilim Dalı Eski Türk Edebiyatı Bilim Dali.

Çörtü, M. M., (2010). Arapça dilbilgisi sarf. İstanbul: M.Ü İlâhiyat Fakültesi Vakfı Yayınları.

Derin, F. Ç., (1988). TDV İslâm ansiklopedisi. Abdi paşa, nişancı. İstanbul, Türkiye. 11(5), 2020 tarihinde https://islamansiklopedisi.org.tr adresinden alınd1

Feridüddin-i Attar. (1993). Pendname. (M. Gençosman, Çev.) İstanbul: MEB.

Kamçı, M., (2019). Feridüddîn Attâr'ın pend-nâmesi'nin bdurrahmân Abdî Paşa Şerhi Müfíd (35a-105a Varakları Arası İnceleme-Metin). (Yayınlanmamış yüksek lisans tezi). Erzincan: Erzincan Binali Yıldırım Üniversitesi Sosyal Bilimleri Enstitüsü Türk Dili ve Edebiyatı Anabilim Dalı.

Müfîd, DİB Yazmalar Kitaplığının 004371 numarada yer alan yazması kullanılmıştır. https://yazmaeserler.diyanet.gov.tr/resource?itemId=10389\&dkymId=60453 05.11 .2020

Naml,, A., (2001). İsmâil Hakk1 Bursevî. 23. İstanbul. 11(5), 2020 tarihinde https://islamansiklopedisi.org.tr adresinden alınd 1

Paksoy, K., (2012). Bursevî İsmaîl Hakkı şerh-i pend-i attâr (İnceleme-Metin-Sözlük). (Yayınlanmamış doktora tezi). Kayseri: Erciyes Üniversitesi Sosyal Bilimler Enstitüsü Türk Dili ve Edebiyatı Anbilim Dalı Eski Türk Edebiyatı Bilim Dalı.

Şerh-i pend-name-i Attar [mikroform]/ Şarih: İsma'il Hakkı Bursavi; müstensih: Şerif Ali b.Fevzî Sandaka1-zade Bursavî Tilmizi, 1963. Mf1994 A 3909.

Yerdemir, F., (2019). Sûdî'nin Gülistân ve Bostan şerhlerinde Türkçe deyimler. Bilig-Türk Dünyast Sosyal Bilimler Dergisi, (90), ss. 191-214. 